\title{
Value of endometrial aspiration cytology in assessing the endometrial status in symptomatic peri and postmenopausal women and its histological correlation with fractional curettage
}

\author{
M. Vennila*, Thangalakshmi
}

Department of Obstetrics and Gynecology, Tirunelveli Medical College and Hospital, Tirunelveli, Tamil Nadu, India

Received: 15 December 2020

Accepted: 31 December 2020

\section{*Correspondence:}

Dr. M. Vennila,

E-mail: arvindr84@gmail.com

Copyright: () the author(s), publisher and licensee Medip Academy. This is an open-access article distributed under the terms of the Creative Commons Attribution Non-Commercial License, which permits unrestricted non-commercial use, distribution, and reproduction in any medium, provided the original work is properly cited.

\section{ABSTRACT}

Background: Abnormal uterine bleeding (AUB) is associated with a wide variety of endometrium. Endometrial interpretation is valuable not only to find the etiology of AUB but also to rule out any organic cause for abnormal uterine bleeding. Fractional curettage is one of the most reliable and commonly performed diagnostic techniques used in the investigation of AUB. To evaluate the efficacy of endometrial aspiration cytology in the diagnosis of abnormal uterine bleeding by correlating it with histopathology.

Methods: This comparative study to be conducted in100 patients attending antenatal clinic at Department of OBG, Tirunelveli Government medical college hospital from January 2018- July 2019. (17) months. Specific investigations like abdominal ultrasonography, thyroid profile, platelet count, bleeding time, clotting time, prothrombin time, etc were done whenever required. Informed consent was taken from all the study patients. Prior to Fractional curettage, endometrial aspiration was done using plastic disposable pipelines of $3 \mathrm{~mm}$ diameter.

Results: The sensitivity of the cytology in detecting carcinoma of the endometrium was $83.3 \%$. The specificity of cytology is $100 \%$. Hence the test is highly specific in diagnosis. The positive predictive value is also $100 \%$ and the negative predictive value is $99 \%$.

Conclusions: It can also detect a few of the endometrial pathologies like endometrial hyperplasia, atrophy, and atypia. It is office Procedure. reduction in associated surgical risks, expense, post-operative pain, and need for operative anesthesia as seen in fractional curettage.

Keywords: Dysfunctional uterine bleeding, Dilatation and curettage, Atrophic endometrium, Polymenorrhoea

\section{INTRODUCTION}

Abnormal uterine bleeding (AUB) is defined as abnormal bleeding from the uterus in the absence of any organic pathology of the genital tract. ${ }^{1}$ AUB is one of the most frequently encountered conditions in the gynecological practice and accounts for approximately $10 \%$ of all new patients in both hospital and private practice. AUB is associated with a wide variety of endometrium. ${ }^{2}$ Endometrial interpretations is valuable not only to find the etiology of AUB but also to rule out any organic cause for abnormal uterine bleeding. Fractional curettage is one of the most reliable and commonly performed diagnostic techniques used in the investigation of AUB. But this involves the cost of hospitalization and operation theaters, bed shortages, and risk of anesthesia. There is also an increasing demand for women to participate in family income. For these reasons, there is a need for a simple, accurate, inexpensive, and good outpatient procedure as an alternative to Fractional curettage. One of the major difficulties encountered in the cytologic study of the endometrium has been related to the inability to 
obtain a satisfactory and representative cellular sample consistently. $^{3}$ The development of a technique for sampling the endometrium was encouraged by Papanicolau himself, who acknowledged the inadequacy of the cervical smear for detecting endometrial pathologies. ${ }^{4}$ Furthermore, any technique to be acceptable by the physician must be one that is easily utilized in his office and cause minimal patient discomfort. An attempt was made by various authors to find out a simple and accurate method to obtain the endometrial sample. These authors opined that the endometrial aspiration technique was an acceptable and valuable method of assessing the endometrium which can be taken up as an OPD procedure. ${ }^{5}$ In this study an attempt has been made to evaluate the efficacy of endometrial aspiration cytology in the diagnosis of abnormal uterine bleeding by taking histologic its being correlated with histopathological examination findings.

\section{METHODS}

This comparative study to be conducted in100 patients attending antenatal clinic at Department of OBG, Tirunelveli Government medical college hospital from January 2018 - July 2019. (17) months.

\section{Inclusion criteria}

All symptomatic peri and post-menopausal women age above 40 yrs diagnosed as AUB were included in this study.

\section{Exclusion criteria}

Cases with known organic genital causes for abnormal uterine bleeding, age less than $40 \mathrm{yrs}$, and pregnant woman excluded from this study.

Detailed clinical history, physical examination, and routine investigations were done in all the study patients. Specific investigations like abdominal ultrasonography, thyroid profile, platelet count, bleeding time, clotting time, prothrombin time, etc were done whenever required.

Informed consent was taken from all the study patients. Prior to fractional curettage, endometrial aspiration was done using plastic disposable pipelines of $3 \mathrm{~mm}$ diameter. No premedication was given. The procedure was carried out on a flat table. The patient was made to lie in the dorsal lithotomy position. Per speculum and vaginal examination was done. Taking all the aseptic precautions, the plastic pipeline was introduced into the uterine cavity. Endometrial aspiration was done, the material obtained was expelled on to clean glass slides and smears were prepared. Few of the smears were dry fixed and stained with giemsa stain. Others were placed in a coplin jar containing 95\% ethanol for half an hour for fixation. These slides were then stained with papanicolaou stain and hematoxylin and Eosin stain. Then fractional curettage was done for the patient under general anesthesia. The endometrial tissue obtained from these procedures was subjected to histopathological study. Interpretation of endometrial aspiration cytology smears. The cytological diagnosis was then correlated with the histopathological diagnosis.

\section{Statistical analysis}

Statistical data is represented by diagrammatic presentations and tabulations. Sensitivity, specificity, and positive predictive value are analyzed. Data collected is analyzed using the chi-square test. $\mathrm{P}$ value of $<0.05$ is considered statistically significant.

\section{RESULTS}

Table 1 shows the age group of the patients ranged from 40 years to 50 years with a maximum number of cases in the range of 40 to 50 years (71). Only cases (19) were found to be more than 50 years. The remaining 10 cases coming under the age of 35 to 40 .

Table 1: Relative risk of abnormal Doppler indices with adverse perinatal outcome.

\begin{tabular}{|lll|}
\hline Age group (years) & Frequency & Percentage \\
\hline $\mathbf{3 0}-\mathbf{4 0}$ & 10 & 10 \\
\hline $\mathbf{4 1 - 5 0}$ & 71 & 71 \\
\hline $\mathbf{5 1 - 6 0}$ & 12 & 12 \\
\hline$>\mathbf{6 1}$ & 7 & 7 \\
\hline Total & 100 & 100 \\
\hline
\end{tabular}

Table 2 shows DUB can present with varied patterns of menstrual irregularities like menorrhagia, irregular cycles, polymenorrhoea, polymenorrhagia, oligomenorrhoea, etc. menorrhagia is the most common complaint among patients with AUB.

Table 2: Complaints distribution of study population.

\begin{tabular}{|ll|l|}
\hline Complaints & Frequency & Percentage \\
\hline $\begin{array}{l}\text { Abnormal uterine } \\
\text { bleeding }\end{array}$ & 71 & 71 \\
\hline $\begin{array}{l}\text { Postmenopausal } \\
\text { bleeding }\end{array}$ & 12 & 12 \\
\hline Menorrhagia & 9 & 9 \\
\hline $\begin{array}{l}\text { Perimenopausal } \\
\text { bleeding }\end{array}$ & 5 & 5 \\
\hline Prolapse & 3 & 3 \\
\hline \hline Total & 100 & 100 \\
\hline
\end{tabular}

Table 3 shows DUB is associated with a wide variety of endometrial patterns which can be both normal and abnormal. Interpretation of endometrial patterns is essential to know the etiology of AUB and also to rule out any organic cause for abnormal bleeding. In the present study, the proliferative type of endometrium was the most common accounting for $61.5 \%$ of all the cases. 
Secretory endometrium (25.5\%) and atrophic endometrium (3\%) were also seen. Abnormal endometrial patterns like simple \& complex endometrial hyperplasia, disordered proliferative endometrium, decidualized endometrium were also detected. One case of gestational endometrium was reported in a patient clinically diagnosed as AUB. On endometrial aspiration, only hemorrhagic material was noted. Hence no opinion was possible and the diagnosis was given based only on histopathological findings.

Table 3: Endometrial pattern on cytology.

\begin{tabular}{|lll|}
\hline $\begin{array}{l}\text { The endometrial pattern } \\
\text { on cytology }\end{array}$ & Frequency & Percentage \\
\hline $\begin{array}{l}\text { Proliferative } \\
\text { endometrium }\end{array}$ & 52 & 52 \\
\hline Secretory endometrium & 13 & 13 \\
\hline Atrophic endometrium & 6 & 6 \\
\hline Endometrial hyperplasia & 13 & 13 \\
\hline $\begin{array}{l}\text { Inflammatory } \\
\text { endometrium }\end{array}$ & 4 & 4 \\
\hline $\begin{array}{l}\text { Endometrial cells with } \\
\text { reactive atypia }\end{array}$ & 5 & 5 \\
\hline No endometrial cells & 4 & 4 \\
\hline Inadequate sampling & 3 & 3 \\
\hline Total & 100 & 100 \\
\hline
\end{tabular}

Table 4 shows $100 \%$ cyto-histo correlation was obtained in the diagnosis of a proliferative, secretory, and atrophic endometrium. In $95 \%$ of cases, there was a correlation between cytological findings and histopathological diagnosis.
Table 4: Endometrial pattern on histology.

\begin{tabular}{|lll|}
\hline $\begin{array}{l}\text { The endometrial pattern } \\
\text { on histology }\end{array}$ & Frequency & Percentage \\
\hline Disorderly Proliferative & 16 & 16 \\
\hline $\begin{array}{l}\text { Degenerative } \\
\text { proliferative }\end{array}$ & 1 & 1 \\
\hline $\begin{array}{l}\text { Proliferative } \\
\text { Endometrium }\end{array}$ & 35 & 35 \\
\hline Secretory Endometrium & 12 & 12 \\
\hline Atrophic endometrium & 5 & 5 \\
\hline $\begin{array}{l}\text { Simple endometrial } \\
\text { hyperplasia }\end{array}$ & 13 & 13 \\
\hline $\begin{array}{l}\text { Inflammatory } \\
\text { endometrium }\end{array}$ & 2 & 2 \\
\hline Hormone induced & 7 & 7 \\
\hline $\begin{array}{l}\text { Endometrial cells with } \\
\text { reactive atypia } \\
\text { (carcinoma changes) }\end{array}$ & 6 & 6 \\
\hline No endometrial cells & 6 & 6 \\
\hline Total & 100 & 100 \\
\hline
\end{tabular}

Table 5 shows significant abnormality went undetected by the cytological method that was also demonstrated histologically. The difficulty of the cytological interpretation of endometrial abnormalities is well known. This is probably because only small cytomorphologic differences are seen between normal and abnormal endometrial patterns. The cytologic evaluation of endometrial hyperplasia is even more difficult and many authors have stated that the cyst diagnosis of endometrial hyperplasia is impossible as they did not show any characteristic features.

Table 5: Percent agreement between cytology and histology

\begin{tabular}{|llll|}
\hline Endometrial pattern & $\begin{array}{l}\text { Number of cases } \\
\text { diagnosed on cytology }\end{array}$ & $\begin{array}{l}\text { Number of cases diagnosed } \\
\text { on histology }\end{array}$ & $\begin{array}{l}\text { Percentage } \\
\text { correlation }\end{array}$ \\
\hline Proliferative endometrium & 52 & 52 & 100 \\
\hline Secretory endometrium & 13 & 12 & 92.3 \\
\hline Atrophic endometrium & 6 & 5 & 83.3 \\
\hline Endometrial hyperplasia & 13 & 10 & 77 \\
\hline Inflammatory endometrium & 4 & 2 & 50 \\
\hline Endometrial cells with reactive atypia & 5 & 6 & 83.3 \\
\hline No endometrial cells & 4 & 6 & 66.6 \\
\hline
\end{tabular}

Table 6 shows there was a perfect cyto-histo correlation in cases of proliferative endometrium, secretory endometrium, atrophic endometrium. All the 52 cases diagnosed as proliferative endometrium on histology were reported as proliferative endometrium on cytology. Distinguishing between proliferative endometrium and disordered proliferative endometrium was not possible on cytology. 10 cases of endometrial hyperplasia were diagnosed on histology and 13 cases in cytology 3 cases were misdiagnosed in cytology. On cytology, simple and complex endometrial hyperplasia should not be differentiated. 5 cases were correctly diagnosed as endometrial cells with reactive atypia in cytology same as in histology. 1 case diagnosed as carcinoma in histology was misdiagnosed as endometrial hyperplasia in cytology. IN cytology there was no differentiation into what type of carcinoma. Histology was able to give the type of carcinoma.

Table 7 shows the sensitivity of the cytology in detecting carcinoma of the endometrium was $83.3 \%$. The specificity of cytology is $100 \%$. Hence the test is highly 
specific in diagnosis. The positive predictive value is also $100 \%$ and the negative predictive value is $99 \%$. Hence the positivity of the test implies a high probability of the disease.

Table 6: Analysis of endometrial pattern mis-diagnosed by cytology

\begin{tabular}{|c|c|}
\hline Cytology & Histology \\
\hline 52 cases of proliferative endometrium & 52 cases of proliferative endometrium \\
\hline $\begin{array}{l}1 \text { case was misdiagnosed as secretory endometrium in } \\
\text { cytology }\end{array}$ & 7 - hormone-induced changes \\
\hline $\begin{array}{l}3 \text { cases misdiagnosed as atrophic } \\
\text { endometrium in cytology }\end{array}$ & $\begin{array}{l}\text { - endometrial adenomatous } \\
\text { - proliferative endometrium }\end{array}$ \\
\hline $\begin{array}{l}3 \text { cases were misdiagnosed as endometrial hyperplasia in } \\
\text { cytology }\end{array}$ & $\begin{array}{l}1 \text { - endometrial cells with atypia } 1 \text { - inflammatory } \\
\text { changes } \\
1 \text { - proliferative endometrium }\end{array}$ \\
\hline 2 cases misdiagnosed as inflammatory & 2 - proliferative endometrium in histology \\
\hline $\begin{array}{l}5 \text { cases were correctly diagnosed as endometrial cells with } \\
\text { reactive atypia } 1 \text { case diagnosed as carcinoma in histology } \\
\text { was misdiagnosed as } \\
\text { endometrial hyperplasia in cytology }\end{array}$ & $\begin{array}{l}6 \text { - cases of endometrial cells with reactive atypia } \\
4 \text { - Endometrial adenocarcinoma } 1 \text { - carcinoma sarcoma } \\
1 \text { - hyperplasia with atypia and necrosis }\end{array}$ \\
\hline
\end{tabular}

Table 7: Sensitivity and specificity of test in diagnosing carcinoma.

\begin{tabular}{|llll|}
\hline $\begin{array}{l}\text { Cytological } \\
\text { diagnosis }\end{array}$ & \multicolumn{2}{l}{ Histological diagnosis } & Total \\
\cline { 2 - 4 } Positive & 5 & 0 & 5 \\
\hline Negative & 1 & 94 & 95 \\
\hline Total & 6 & 94 & 100 \\
\hline
\end{tabular}

Table 8: Sensitivity and specificity of test in diagnosing dysfunctional uterine bleeding.

\begin{tabular}{|lll|l|}
\hline $\begin{array}{l}\text { Cytological } \\
\text { diagnosis }\end{array}$ & \multicolumn{2}{|c|}{ Histological diagnosis } & \multirow{2}{*}{ Normal } \\
\cline { 1 - 2 } & $\begin{array}{l}\text { Abnormal } \\
\text { endometrium }\end{array}$ & \\
\hline $\begin{array}{l}\text { Normal } \\
\text { endometrium }\end{array}$ & 59 & 6 & 65 \\
\hline $\begin{array}{l}\text { Abnormal } \\
\text { endometrium }\end{array}$ & 2 & 28 & 30 \\
\hline Total & 61 & 35 & 100 \\
\hline
\end{tabular}

Table 8 shows the sensitivity of the cytology in detecting abnormal endometrium from normal endometrium was $96 \%$. The specificity of cytology is $80 \%$. Hence the test is highly sensitive in diagnosing abnormal endometrium from normal changes. The positive predictive value is $91 \%$ and the negative predictive value is $93.3 \%$. Hence the positivity of the test implies a high probability of the abnormal endometrium.

\section{DISCUSSION}

It is an accepted medical fact that women with a history or evidence of abnormal uterine bleeding require investigations. Diagnostic D and C is the most reliable and common method to detect endometrial pathology. ${ }^{6}$ But this requires hospitalization, operating rooms besides the risk of anesthesia. Hence there is a need for a simple and good outpatient procedure as an alternative to D\&C. Though the vaginal smear is also used in the detection of endometrial pathology, direct sampling proves to be more reliable. $^{7}$ The length of time the endometrial cells take to reach the vaginal pool, alterations in $\mathrm{pH}$, inflammatory conditions of cervix and vagina, and dilution of cytological material by other secretions in the posterior pool- all materially alter the morphological features of the cells and render the diagnosis difficult. Also, confusion may occur between the endometrial cells and endocervical cells. ${ }^{8} \mathrm{~A}$ wide variety of appliances have been used for endometrial aspiration by various authors like intrauterine aspiration cannula, isaacs endometrial cell sampler, vabra aspirator, uterobrush, endocyte, pipelle, karman's cannula, etc. ${ }^{9}$ The amount of material obtained, the appearance of cells and their distribution largely depend on the technique used for collection, processing, and staining. In our study, 100 patients with dysfunctional uterine bleeding were subjected to endometrial aspiration using a $3 \mathrm{~mm}$ diameter plastic disposable pipeline. ${ }^{10}$ Adequate materials was obtained in $99 \%$ of the cases which rank well when compared with other studies. The cellular morphology was well maintained in all the smears. Dysfunctional uterine bleeding is a common cause for abnormal uterine bleeding amounting to $10 \%$ of all gynecological patients. It commonly occurs in reproductive and perimenopausal age groups. DUB is also one of the common causes of postmenopausal bleeding. In such cases, careful screening for malignancy is imperative and should be treated promptly. ${ }^{11}$ In our study the maximum number of cases was seen in the age group of 41-50 years $(45.5 \%) .{ }^{4}$ cases of postmenopausal bleeding were diagnosed as DUB in whom no endometrial pathology was detected both by cytology and histopathology. ${ }^{12}$ DUB can present with varied patterns of menstrual irregularities like menorrhagia, irregular cycles, polymenorrhoea, polymenorrhagia, oligomenorrhoea, etc. menorrhagia is the most common complaint among patients with AUB. 
DUB is associated with a wide variety of endometrial patterns which can be both normal and abnormal. ${ }^{13}$ Interpretation of endometrial patterns is essential to know the etiology of AUB and also to rule out any organic cause for abnormal bleeding. In the present study, the proliferative type of endometrium was the most common accounting for $61.5 \%$ of all the cases. Secretory endometrium $(25.5 \%)$ and atrophic endometrium (3\%) were also seen.14 Abnormal endometrial patterns like simple\& complex endometrial hyperplasia, disordered proliferative endometrium, decidualized endometrium were also detected. ${ }^{15}$ One case of gestational endometrium was reported in a patient clinically diagnosed as AUB. ${ }^{16}$ On endometrial aspiration only hemorrhagic material was noted. Hence no opinion was possible and the diagnosis was given based only on histopathological findings. $100 \%$ cyto-histo correlation was obtained in the diagnosis of a proliferative, secretory, and atrophic endometrium. ${ }^{17}$ In $95 \%$ of cases there was a correlation between cytological findings and histopathological diagnosis. No significant abnormality went undetected by the cytological method that was also demonstrated histologically. The difficulty of the cytological interpretation of endometrial abnormalities is well known. ${ }^{18}$ This is probably because only small cytomorphologic differences are seen between normal and abnormal endometrial patterns. The cytologic evaluation of endometrial hyperplasia is even more difficult and many authors have stated that the cyst diagnosis of endometrial hyperplasia is impossible as they did not show any characteristic features. ${ }^{19}$ In the present study we were unable to distinguish disordered proliferative endometrium from proliferative endometrium by aspiration cytology study. Distinguishing between simple and complex endometrial hyperplasia was also not possible on cytology. Morton DG et al also states that on cytology diagnosis of hyperplasia could be made easily but the degree of hyperplasia was possible to diagnose only on histopathological sections. ${ }^{20}$

\section{CONCLUSION}

Endometrial aspiration cytology can be used as an outpatient procedure. Best screening technique for the cases of AUB using the pipeline. Aspirated material using pipeline can also be used for histopathological examination and diagnosis if the patient is not fit for anesthetic assessment for any procedure under anesthesia. It has got higher diagnostic accuracy. Proliferative endometrium was the most common pattern (53\%) observed. Abnormal endometria like simple and complex endometrial hyperplasia, disordered proliferative endometrium, atrophic endometrium, decidualized endometrium were also detected. The sensitivity of the cytology in detecting carcinoma of the endometrium was $83.3 \%$. The specificity of cytology is $100 \%$. Hence the test is highly specific in diagnosis. The positive predictive value is also $100 \%$ and the negative predictive value is $99 \%$. Hence the positivity of the test implies a high probability of the disease.

Funding: No funding sources

Conflict of interest: None declared

Ethical approval: The study was approved by the Institutional Ethics Committee

\section{REFERENCES}

1. Affandi MZ, Joseph R, Minish SR, Doctor V. Single endometrial aspiration for detection of ovulation. Int J Gynecol Obst. 1983;21:395- 401.

2. Anderson MG, Eaton CJ, Galinkim LJ, Newton CW, Haines JP, Miller NF. The cytologic diagnosis of endometrial adenocarcinoma. Am J Obstet Gynecol. 1976;125:376-83.

3. Ayre JE. Rotating endometrial brush; a new technique for diagnosis of fundal carcinoma.

4. Barbaro CA, Fortune DW, Bodey AS. Uterine lavage in the diagnosis of endometrial malignancy and its precursors. Acta Cytol. 1982;26:135-40.

5. Byrne AJ. Endocyte endometrial smears in the cyst diagnosis of endometrial carcinoma. Acta Cytol. 1990;34:373-81.

6. Cardoso PM, D'Silva EA. Dysfunctional uterine bleeding- A review. J Obs Gynae. 2004;9(1):47-50.

7. Cary WH. A method of obtaining endometrial smears for the study of their cellular contents. Am J Obst Gynec. 1943; 46:422-3.

8. Chakravarthy A. Diagnostic efficacy of endometrial cytology. Obstet Gynecol. 1986;134:147-51.

9. Crow J, Gordon H, Hudson E. An assessment of the Mi- Mark endometrial sampling technique. J Clin Pathol. 1980;33(1):72-80.

10. Davey DA. Dysfunctional uterine bleeding. In: Keith ED, editor. Dewhurst's Textbook of Obstetrics and Gynaecology for Postgraduates. 5th ed. New Delhi: Blackwell scientific publications; 1995;590-608.

11. Dowling EA, Gravlee LC. Endometrial cancer diagnosis: a new technique using a jet washer. Ala $\mathbf{J}$ Med Sci. 1964;1:412-6.

12. Fothergill DJ, Brown VA, Hill SA. Histological sampling of the endometrium- A comparison between formal curettage and the Pipelle sampler. $\mathrm{Br}$ J Obstet Gynaecol. 1992;99:779-80.

13. Fox CH, Turner FG, Johnson WL, Thornton NW. Endometrial cytology- A new technique. Am J Obst Gynec. 1962;83(12):1582-91.

14. Ginsberg NA, Padleckas R, Javaheri G. Diagnostic reliability of Mi-Mark helix technique in endometrial neoplasia. Obstet Gynecol. 1983;62(2):225-30.

15. Hecht EL. The endometrial aspiration smear; research status and clinical value. Am J Obst Gynec. 1956;71(4):819-33.

16. Isaacs J, Wilhoitte R. Aspiration cytology of the endometrium: office and hospital sampling procedures. Obstet Gynecol. 1974;118:679-87. 
17. Jensen JG. Vacuum curettage, outpatient curettage without anesthesia: a report of 350 cases. Dan Med Bull. 1970;17:199-202.

18. Jordan MJ, Bader GM, Nemazie AS. Comparative accuracy of preoperative cytology and histologic diagnosis in endometrial lesions. Obst Gynec. 1956; 7:646-53.

19. J Abdulameer S. Cytogenetic Analysis of Children with Ambiguous Genitalia in Mosul. Rafidain J Sci. 2012;23(5):33-7.
20. Morton DG, MooreJG, Chang N. Endometrial lavage as an aid in the diagnosis of carcinoma of the endometrium. West J Surg Obstet Gynecol. 1957;65:113-9.

Cite this article as: Vennila M, Thangalakshmi. Value of endometrial aspiration cytology in assessing the endometrial status in symptomatic peri and postmenopausal women and its histological correlation with fractional curettage. Int J Reprod Contracept Obstet Gynecol 2021;10:717-22. 